\title{
Delay of sexual maturation in female house mice by exposure to grouped females or urine from grouped females
}

\author{
L. C. Drickamer \\ Biology Department, Williams College, Williamstown, Massachusetts 01267, U.S.A.
}

\begin{abstract}
Summary. The experiments examined the timing, duration and possible enhancement effects of group contact on the delay of sexual maturation produced in prepubertal female house mice by urine from grouped females. One or three days of pheromone stimulation at specified ages during the first 2 weeks after weaning was not sufficient to delay puberty in females caged singly. However, pheromone treatment for 7 days, beginning during the first week after weaning, did significantly delay the onset of first vaginal oestrus relative to control females treated with water. Both the timing and duration of pheromone stimulation appear to be critical factors affecting pheromoneinduced delay of sexual maturation. Mean ages at first oestrus for females housed with a group of 7 other females, for 3 or 7 days at specified ages during the first 2 weeks after weaning, did not differ from mean ages recorded with urine stimulation only. Contact with other females does not appear to alter or enhance the delay-of-maturation effect achieved with urine stimulation. In all these respects the maturation-delay pheromone of grouped female mice appears to differ from the puberty-accelerating pheromone of male mice.
\end{abstract}

\section{Introduction}

Previous investigations have shown that social and environmental factors may accelerate or delay the timing of sexual maturation of juvenile female mice (Vandenbergh, 1967; Cowley \& Wise, 1972; Drickamer, 1974a). Urinary pheromone stimulation and synergistic social contact from adult male mice have been implicated as factors in the acceleration of puberty (Vandenbergh, 1969; Drickamer, 1974b; Bronson \& Maruniak, 1975), while a pheromone produced by freely-interacting grouped female mice is an important factor affecting the delay of maturation in young female mice housed at different densities (Cowley \& Wise, 1972; Drickamer, 1974a).

The timing and duration of the stimulation could influence the effectiveness of maturationdelaying and maturation-accelerating pheromones. Colby \& Vandenbergh (1974) reported that 3 days of pheromone stimulation with male urine were sufficient to accelerate puberty. In addition they found that the older the young female mouse was at the time of pheromone treatment, the shorter the interval between the treatment and attainment of puberty. The present investigation was designed to test the effects of duration and timing of exposure of young female mice to urine from grouped females on the occurrence of first vaginal oestrus.

\section{Methods and Results}

\section{General}

The ICR/Alb mice were from a random-bred closed-colony stock. The colony and the experimental mice were housed in shoe-box cages of polypropylene, measuring $15 \times 28 \times 15 \mathrm{~cm}$ and with opaque sides and fitted wire lids, in rooms maintained at $21-25^{\circ} \mathrm{C}, 30-60 \%$ relative humidity, and $12 \mathrm{~h}$ light $/ 24 \mathrm{~h}$. The litter of wood shavings in each cage was changed weekly. Wayne Lab Blox and water were freely supplied throughout the investigation.

Pregnant female mice were isolated in individual cages during the last week of gestation. All cages were then checked daily for births. On the day after birth the young in each litter were counted 
and sexed. Each litter was reduced to 10 young, at least 3 of which were males, and litters of less than 10 young were discarded. Young mice were weaned 21 days after birth and were immediately assigned to a treatment group and cage according to a random sequence.

Each mouse was weighed to the nearest $0 \cdot 1 \mathrm{~g}$ on Day 21 . For each experiment a one-way analysisof-variance was performed on the body weight data and there were no significant differences in weaning body weights across the various treatment groups. Each mouse was examined daily from Day 21 until the occurrence of vaginal perforation. Starting on the day of vaginal perforation, a daily vaginal lavage was taken until the occurrence of first vaginal oestrus. Wet-mount vaginal smears were examined immediately with a light microscope and the cellular contents were evaluated to determine stages of the oestrous cycle according to the criteria of Vandenbergh (1969) and Vandenbergh, Drickamer \& Colby (1972).

\section{Experiment I}

This experiment was to determine whether a single day of exposure to the maturation-delaying pheromone produced by grouped female mice would be sufficient to retard puberty in young females.

Methods. At 21 days of age, 240 female mice were weaned and assigned to one of 12 treatment groups according to a random sequence. Each test female was caged individually throughout the study. Test groups of 20 females were each treated once at $21,24,27,30$ or 33 days of age with urine from either grouped (8/cage) adult females (multiparous and aged 120-180 days) or grouped (8/cage) juvenile females (of the same age as the experimental animals). Control females were similarly treated but with water instead of urine. Urine was collected by holding a female over a Petri dish and gently squeezing the flanks. A fine brush was used to apply 0.02 to $0.03 \mathrm{ml}$ urine (or water) to the external nares of each treatment subject on the specified day.

Results. There were no significant differences in the mean ages at first oestrus in any of the treatment groups (Table 1).

\section{Experiment II}

This experiment tested whether 3 days of exposure to the maturation-delaying pheromone would retard puberty in young female mice.

Methods. These were identical to those of Exp. I except that 360 female mice were used for the 12 treatment groups, providing $30 \mathrm{mice} / \mathrm{group}$, and the experimental mice were painted with urine on 3 consecutive days at $21-23,24-26,27-29,30-32$ or 33-35 days of age.

Results. There were again no significant differences in the mean ages at first oestrus in any treatment group (Table 1).

\section{Experiment III}

This experiment was designed to determine whether 1 week of exposure to the maturationdelaying pheromone would retard sexual maturation in young female mice.

Methods. The methods were identical to those of Exp. I except that 200 mice were used, divided into 10 groups of 20 mice each, and the urine treatment lasted for 7 consecutive days beginning on Days $21,24,27$ or 30 of age.

Results. Analyses-of-variance revealed significant differences in the mean ages at first oestrus among the 5 treatment groups for each type of female urine used (Table 1). Mice treated for Days 21-27 and 24-30 with urine from grouped adult females matured significantly later than control females or females painted on Days 30-36. There was an overlapping pattern of significant differences for mice painted with urine from grouped young females. Treatment on Days 21-27 and 24-30 resulted in later mean ages at first oestrus than for untreated controls, and females treated on Days 21-27 reached puberty significantly later than mice painted on Days 27-33 or 30-36. 
Table 1. The mean ( \pm 1 S.E.) age at first vaginal oestrus of female mice exposed to the urine of adult or juvenile females for various periods and at various ages during the first 2 weeks after weaning

\begin{tabular}{|c|c|c|c|}
\hline Exp. (treatment) & $\begin{array}{l}\text { Days of } \\
\text { urine exposure }\end{array}$ & $\begin{array}{l}\text { Urine from } \\
\text { adults }\end{array}$ & $\begin{array}{l}\text { Urine from } \\
\text { juveniles }\end{array}$ \\
\hline \multirow[t]{2}{*}{$\begin{array}{l}\text { I (1 day urine, } \\
20 \text { mice/treatment) }\end{array}$} & $\begin{array}{c}21 \\
24 \\
27 \\
30 \\
33 \\
- \text { (control) }\end{array}$ & $\begin{array}{l}37.1 \pm 1.2 \\
36.9 \pm 0.8 \\
36 \cdot 1 \pm 1.0 \\
35.7 \pm 1 \cdot 1 \\
36.0 \pm 0.9 \\
35.8 \pm 0.9\end{array}$ & $\begin{array}{l}36.4 \pm 1.1 \\
36.6 \pm 0.9 \\
37.0 \pm 1.0 \\
35.8 \pm 0.7 \\
36.0 \pm 0.9 \\
36.2 \pm 1.0\end{array}$ \\
\hline & & $F=1 \cdot 168 ;$ d.f. 5,$114 ;$ N.S. & $F=0.876 ;$ d.f. 5,$114 ;$ N.S. \\
\hline \multirow[t]{2}{*}{$\begin{array}{l}\text { II ( } 3 \text { days urine, } \\
30 \text { mice/treatment) }\end{array}$} & $\begin{array}{l}21-23 \\
24-26 \\
27-29 \\
30-32 \\
33-35 \\
- \text { (control) }\end{array}$ & $\begin{array}{l}38.8 \pm 1 \cdot 4 \\
36.3 \pm 1.2 \\
38.6 \pm 1 \cdot 3 \\
38.1 \pm 1 \cdot 1 \\
38.2 \pm 1 \cdot 7 \\
36.9 \pm 1.0\end{array}$ & $\begin{array}{l}37.6 \pm 1.3 \\
36.8 \pm 1.4 \\
37.8 \pm 1.0 \\
36.4 \pm 1.3 \\
37.9 \pm 1.1 \\
36.6 \pm 1.1\end{array}$ \\
\hline & & $F=1 \cdot 120 ;$ d.f. 5,$179 ;$ N.S. & $F=1.025 ;$ d.f. 5,$179 ;$ N.S. \\
\hline \multirow[t]{2}{*}{$\begin{array}{l}\text { III ( } 7 \text { days urine, } \\
20 \text { mice/treatment) }\end{array}$} & $\begin{array}{c}21-27 \\
24-30 \\
27-33 \\
30-36 \\
- \text { (control) }\end{array}$ & $\begin{array}{l}39 \cdot 3 \pm 1 \cdot 1 \\
40.9 \pm 1.2 \\
37.8 \pm 0.9 \\
37.0 \pm 1.0 \\
35.6 \pm 0.8\end{array} \mid$ & $\begin{array}{l}40.1 \pm 1.3 \\
39.8 \pm 1.4 \\
37.6 \pm 1.2 \\
36.7 \pm 1.1 \\
36.4 \pm 0.9\end{array} \mid$ \\
\hline & & $F=8.498 ;$ d.f. 4,$95 ; P<0.01$ & $\mathrm{~F}=7.685 ;$ d.f. 4,$95 ; P<0.01$ \\
\hline \multirow[t]{2}{*}{$\begin{array}{l}\text { IV ( } 3 \text { days in group, } \\
20 \text { mice/treatment) }\end{array}$} & $\begin{array}{c}21-23 \\
24-26 \\
27-29 \\
30-32 \\
33-35 \\
- \text { (control) }\end{array}$ & $\begin{array}{l}36.2 \pm 1.0 \\
36.4 \pm 1 \cdot 1 \\
36.8 \pm 1 \cdot 1 \\
35.9 \pm 1.2 \\
36.7 \pm 1.4 \\
35.8 \pm 1 \cdot 1\end{array}$ & $\begin{array}{l}35.9 \pm 1.0 \\
37.1 \pm 0.9 \\
36.4 \pm 1.2 \\
36.7 \pm 1 \cdot 1 \\
36.0 \pm 1.0 \\
36.1 \pm 0.9\end{array}$ \\
\hline & & $F=0.984 ;$ d.f. 5,$114 ;$ N.S. & $F=0.872 ;$ d.f. 5,$114 ;$ N.S. \\
\hline \multirow[t]{2}{*}{$\begin{array}{l}V \text { ( } 7 \text { days in group, } \\
20 \text { mice/treatment) }\end{array}$} & $\begin{array}{c}21-27 \\
24-30 \\
27-33 \\
30-36 \\
- \text { (control) }\end{array}$ & $\begin{array}{l}40 \cdot 6 \pm 1 \cdot 2 \\
40 \cdot 2 \pm 1.3 \\
38 \cdot 2 \pm 1 \cdot 2 \\
36 \cdot 1 \pm 0.8 \\
36 \cdot 2 \pm 1.0\end{array} \mid$ & $\begin{array}{l}39.8 \pm 1 \cdot 1 \\
40.2 \pm 1.2 \\
37.9 \pm 1.3 \\
36.5 \pm 1.2 \\
35.9 \pm 0.9\end{array}$ \\
\hline & & $\mathrm{F}=7.162 ;$ d.f. 4,$95 ; P<0.01$ & $F=7.864 ;$ d.f. 4,$95 ; P<0.01$ \\
\hline
\end{tabular}

In Groups III and V the means not connected by the same vertical line are significantly different at the $P<0.05$ level.

\section{Experiments IV and $V$}

These experiments were to determine whether some type of social stimulation, acting in addition to the pheromone, affects the timing of puberty in grouped female mice.

Methods. In Experiment IV 240 female mice were weaned and assigned at random to one of 12 treatment groups. Test mice were housed for 24 h/day with groups of 7 adult or juvenile females, for 3-day periods beginning at 21, 24, 27, 30 or 33 days of age. Twenty cages each containing 7 adult females and 20 cages each containing 7 young females, the same ages as the test subjects, were used for the group exposure. The bedding in these cages was changed each time a new test mouse was added to the group. Before and after being caged with the group each test mouse was caged alone. Control mice were caged alone and not treated. One toe of the right forefoot of each test mouse was clipped so that it could be identified when in the group. 
In Exp. V 200 female mice were used, divided into 10 groups of 20 mice each, and each test mouse was housed with a group of adult or young females for 7 consecutive days beginning at 21 , 24,27 or 30 days of age.

Results. There were no significant differences in the mean ages at puberty in the 12 treatment groups in Exp. IV (Table 1). In Exp. V, however, there were significant differences in the timing of sexual maturation (Table 1); test mice caged with groups of females (adult or young) for 1 week from 21 or 24 days of age matured later than those exposed on Days 30-36 of age or maintained as untreated controls.

\section{Discussion}

The results from these five experiments support the following conclusions. (1) The timing and duration of stimulation from maturation-delaying pheromone produced by grouped female mice are significant factors in retarding the onset of puberty. (2) Physical contact and interaction with a group of female mice produces no additional delay in sexual maturation beyond that achieved by pheromone treatment. (3) No apparent difference exists between the effects of maturation-delaying pheromone(s) produced by grouped juvenile and adult female mice.

The results of Exp. I and II demonstrated that 1 or 3 days of pheromone treatment during the first 2 weeks after weaning were not sufficient to delay the onset of first vaginal oestrus in young female mice. However, application of urine from grouped females for 7 consecutive days, beginning at 21 or 24 days of age, did produce significant delays in sexual maturation (Exp. III).

It seemed possible that the higher mean ages (than in control mice) at first oestrus in mice treated from 30 or 33 days of age resulted from the fact that some mice had already attained oestrus before urine treatment began, giving rise to a bimodal distribution of ages at first oestrus. However, a check of the individual records showed that only 1 mouse of the group treated from 30 days of age had reached first oestrus before treatment and only 3 of those for which treatment began at 33 days of age. Higher variance estimates than those in other groups would also have been expected if there had been a bimodal distribution of age at first oestrus.

It therefore appears (i) that more than 3 days of stimulation with grouped female urine is necessary for achieving a delay in puberty and (ii) that the urine treatment must commence by at least 6 or 7 days after weaning. Cowley \& Wise (1972) have previously shown that stimulation with grouped female mouse urine before weaning can significantly delay sexual maturation.

Colby \& Vandenbergh (1974) found that 3 days of urine stimulation with the male-produced pheromone which accelerates sexual maturation was sufficient to produce earlier mean ages at first oestrus than in untreated controls. They also reported that the older the mouse was at the time of urine treatment, the faster its subsequent sexual development. They suggested that exposure to adult male mouse urine does not trigger puberty, but instead accelerates an ongoing process. Our results from Exp. III suggest that the maturation-delaying pheromone produced by grouped female mice acts either to block temporarily or to slow down the ongoing sexual development process.

The results of Exps IV and V indicate that the delay-of-maturation effect produced when females are caged in groups appears to be a function solely of the pheromone and the effect is not altered or enhanced by social contact. The delay of sexual maturation is not altered if ovariectomized females are used in these groups and young females treated with urine from grouped ovariectomized females also have a delayed first oestrus (unpublished), indicating that ovarian hormones are not necessary for the production and/or secretion of the maturation-delaying pheromone. Drickamer (1974a) has previously shown that free social interaction among the grouped female mice is necessary for production of this pheromone. Previous studies of the acceleration of maturation by the male have established that both a urinary pheromone and synergistic social cues are important factors influencing the timing of puberty (Drickamer, 1974b; Bronson \& Maruniak, 1975).

The present results also confirm earlier work (Drickamer, 1974a) which indicated that juvenile and adult females housed in groups produce the maturation-delaying pheromone. The question of whether the pheromone(s) produced by young and adult females are identical must await chemical 
analyses. In contrast to these findings for females, the acceleratory pheromone is produced only by adult intact males, and not by either juvenile or castrated males (Colby \& Vandenbergh, 1974; Drickamer \& Murphy, 1977).

The two pheromone systems which affect the timing of puberty in house mice, male-induced acceleration and grouped-female-induced delay, clearly differ in several ways. (1) For male acceleration of maturation, synergistic social cues may enhance the effect of the urinary pheromone, whereas for grouped females social contact, while necessary for pheromone production, does not enhance the delay of sexual development. (2) Only adult intact males produce maturation-accelerating pheromone, but juvenile and adult females are capable of producing the maturation-delaying pheromone. (3) A short period of 3 days of male-urine stimulation is sufficient to accelerate puberty, but more than 3 days of treatment with urine from grouped females is required to delay maturation. As more investigations are conducted these differences in the two pheromone systems affecting the timing of puberty may become important to our understanding of population regulation and the control of generation time in house mice.

The author was supported, in part, by a National Institutes of Child Health and Development award No. HD-08585 from the United States Public Health Service. I thank Ms Valerie Dohrenwend for her technical assistance and Dr C. R. Terman and Dr T. E. McGill for their helpful comments on the manuscript.

\section{References}

Bronson, F.H. \& MaruniaK, J.A. (1975) Male-induced puberty in female mice: evidence for a synergistic action of social cues. Biol. Reprod. 13, 94-98.

Colby, D.R. \& VANDEnbergh, J.G. (1974) Regulatory effects of urinary pheromones on puberty in the mouse. Biol. Reprod. 11, 268-279.

COWLEY, J.J. \& WiSE, D.R. (1972) Some effects of mouse urine on neonatal growth and reproduction. Anim. Behav. 20, 499-506.

Drickamer, L.C. (1974a) Sexual maturation of female mice: social inhibition. Devl Psychobiol. 7, 257-265.

Drickamer, L.C. (1974b) Contact stimulation, androgenized females and accelerated sexual development in female mice. Behav. Biol. 12, 101-110.
Drickamer, L.C. \& MURPhy, R.X. (1977) Female mouse maturation: effects of excreted and bladder urine from juvenile and adult males. Devl Psychobiol. (in press).

VANDENBERGH, J.G. (1967) Effect of the presence of a male on the sexual maturation of female mice. Endocrinology 81, 345-349.

VANDENBERGH, J.G. (1969) Male odor accelerates female sexual maturation in mice. Endocrinology 84, $658-660$.

Vandenbergh, J.G., Drickamer, L.C. \& Colby, D.R. (1972) Social and dietary factors in the sexual maturation of female mice. J. Reprod. Fert. 28, 397405.

Received 21 December 1976 